\title{
Spatial Diversity in the Socio-Economic Development in Sub-Saharan Africa as Measured by a Composite Index
}

\author{
Agnieszka Witoń
}

\begin{abstract}
A B S T R A C T
Objective: The main aim of the article is to present the level of the socio-economic development in Sub-Saharan Africa's sub-regions: West Africa, South Africa, East Africa, and Central Africa. The second aim is to identify whether some of the subregions have significantly different level of the socio-economic development in comparison to the others.
\end{abstract}

Research Design \& Methods: A composite index of development has been created. Hypotheses are verified through statistical analysis (including parametric tests).

Findings: Sub-Saharan countries do not differ significantly in the socio-economic development level. No sub-region has a significantly higher (or lower) level of development in comparison to the others. However, after eliminating Seychelles from the analysis (as an outlier value) East Africa proves to be significantly lower developed than the whole region and other sub-regions.

Implications \& Recommendations: The lack of significant differences in the level of the socio-economic development in Sub-Saharan countries proves that analysing them as one group is justified.

Contribution \& Value Added: A new composite index of the socio-economic development has been created to test the hypotheses.

\begin{tabular}{|c|c|}
\hline Article type: & research paper \\
\hline Keywords: & $\begin{array}{l}\text { socio-economic development; developing countries; } \\
\text { Sub-Saharan Africa }\end{array}$ \\
\hline JEL codes: & $130,010,055$ \\
\hline
\end{tabular}

\section{Suggested citation:}

Witoń, A. (2015). Spatial diversity in the socio-economic development in Sub-Saharan Africa as Measured by a Composite Index. Entrepreneurial Business and Economics Review, 3(1): 75-85, DOI: http://dx.doi.org/ 10.15678/EBER.2015.030106. 


\section{INTRODUCTION}

Recent years brought a lot of attention to Sub-Saharan Africa. Its economic growth is widely discussed by both scholars and businessmen. This hardly comes as a surprise, since Sub-Saharan Africa is one of the most rapidly developing regions in the world. In the last ten years the average yearly GDP growth has reached almost $5 \%$. However, this signifies a quantitative change only. A more thorough approach to the issue of growth demands taking into account some qualitative aspects as well. Sub-Saharan Africa, despite its dynamic growth, remains one of the poorest regions of the world. In 2013 the average GDP per capita in the region amounted to 1015.83 USD. This is even less than in South Asia, where the average GDP per capita in 2013 was 1060.66 USD.

These numbers, though certainly not favourable, fail to show the severity of the situation in terms of the socio-economic development in Sub-Saharan Africa. Afrobarometer, a household survey from 2013, shows that about a fifth of the Africans has their most basic needs unsatisfied regularly: $17 \%$ suffer from lack of food, $21 \%$ from lack of clean water, and $20 \%$ do not have access to medicine and basic medical care. As much as a half of the Africans declare being deprived of those things occasionally (Dulani, Mattes, \& Logan, 2013). This situation calls for a wider approach to Africa's, and especially Sub-Saharan Africa's growth. It cannot be said that a country is developing when people's most basic needs are not being met or there are no successful attempts to relieve the situation.

This article attempts to shed some more light on the issue of the socio-economic development in Sub-Saharan Africa. Its first aim is to present the level of the socioeconomic development in Sub-Saharan Africa's sub-regions: West Africa, South Africa, East Africa, and Central Africa. The second aim of the article is to identify whether some of the sub-regions have significantly different level of the socio-economic development in comparison to the others.

\section{LITERATURE REVIEW}

The topic of the economic development in Sub-Saharan Africa has been raised many times in the literature. Most works concerning this region focus on the determinants of the recent rapid economic growth or, alternatively, on factors that impeded Sub-Saharan Africa's development in the past. Both economic and non-economic factors are widely discussed.

One of the most widely cited papers concerning the economic development in SubSaharan Africa, authored by Sachs and Warner (1997), is based on a cross-country regression model; it links slow economic growth with poor macroeconomic policies, low openness to the international trade, and various geographical factors: limited access to the sea, climate, and propensity for infectious diseases. Malaria proves to be the root cause of Africa's underdevelopment according to the study by Bhattacharyya (2009), who also uses a regression model.

Ghura and Hadjimichael (1996) claim that the level of private investment and macroeconomic policy are the main determinants of the GDP per capita growth in SubSaharan Africa's countries. Not the level of investments, but one of savings, as well as the 
technological development, is investigated by Kraay and Raddatz, who use aggregate growth models (2007). They do not find enough empirical evidence of these factors causing so called poverty traps in low-income African countries, though.

Easterly and Levine (1997) construct a cross-country regression model and argue that the diversity of the economic growth within Sub-Saharan countries can be attributed to macroeconomic policies, and, most notably, ethnic differences. They are supposed to have a negative effect on growth and the level of income by playing their part in determining the choice of bad policies. This results have been later disproved by Collier and Hoeffler (1998) with the use of probit and tobit models, and later by Collier and Gunning (1999). Collier and Gunning explain Africa's weak economic performance (in comparison to other regions) with the level of human capital development and the openness to international trade. The relation between human capital and economic growth in Africa is found important also by Boccanfuso, Savard \& Savy (2013).

Political instability is also often found to be an important determinant of economic growth in Sub-Saharan Africa. It is investigated by, among others, Fosu (1992a). GyimahBrempong and Traynor (1999) have analysed the inter-relationship between growth, investment, and political risk. Their study, which used simultaneous equations model, showed that political instability has a significant negative impact on growth.

Foreign aid as a growth determinant in Sub-Saharan Africa has been analysed by Boone (1996); it was found that it has no impact on economic growth. Later, Burnside and Dollar (1997) have shown through OLS growth regressions that aid has positive effect on growth only in low-inflation, small budget deficit, and open countries. In other cases it may have a negative impact on economic growth.

Platteau $(2000,2009)$ argues that social norms common in Sub-Saharan Africa that force and reward sharing of goods, reduce economic incentives, thus causing low economic performance. Acemoglu and Robinson (2010) do not agree with this assessment, claiming that there is no strong empirical evidence supporting such claims. They underline historical and institutional determinants of Sub-Saharan Africa's economic performance: political and economic institutions, history of slave trade, and colonialism. The negative impact of the history of slave trade on economic growth in Africa was also investigated by Nunn (2008), who used basic correlations and OLS estimates.

Among other interesting determinants of economic development in Sub-Saharan Africa, one can mention remittances, the development of agriculture, export instability, and debt. Using a three-stage least squares estimation technique Gupta, Pattillo \& Wagh (2009) find that remittances reduce poverty and positively affect the development of the financial markets in some Sub-Saharan countries. Karshenas (2001), while comparing Asia and Sub-Saharan Africa, finds that the development of the agricultural sector, as well as the natural resources, play an important role in region's development. The impact of export instability on economic growth in Africa is examined by Fosu (1992b). The relationship between debt overhang and economic growth in Sub-Saharan countries is investigated by Elbadawi, Ndulu \& Ndung'u with a simulation model (1997).

In the light of the large inflow of foreign direct investment observed in Sub-Saharan Africa in recent years, one should also mention studies examining the impact of foreign investment on Africa's economic performance. Having constructed a cross-country 
regression model Lumbila (2005) claims that FDI has positive effect on economic growth in Sub-Saharan Africa. On the other hand, the results of the study by Adams (2009) show that foreign direct investment is a necessary but not sufficient condition for economic growth. Chinese investment in Sub-Saharan region is eagerly discussed in particular. Its impact on economic performance of the Sub-Saharan countries is examined by, among others, Kaplinsky, McCornick \& Morris (2007), as well as Gu (2009).

\section{MATERIAL AND METHODS}

The main goal of the article is to present the level of the socio-economic development in Sub-Saharan Africa's sub-regions: West Africa, South Africa, East Africa, and Central Africa. The second goal is to identify whether some of the sub-regions show significantly different level of the socio-economic development in comparison to the others. To achieve these goals, the following hypotheses have been developed:

H1: There are significant differences in the level of the socio-economic development between the sub-regions of Sub-Saharan Africa.

H2: The level of the socio-economic development in South Africa is significantly higher than in other sub-regions of Sub-Saharan Africa.

After eliminating from the analysis countries with extreme values of the level

H3: of the socio-economic development, the differences between sub-regions are no longer significant.

Table 1. Variables used in the composite socio-economic development index

\begin{tabular}{|l|l|l|}
\hline & \multicolumn{1}{|c|}{ Definition } & \multicolumn{1}{c|}{ Source } \\
\hline X1 & $\begin{array}{l}\text { Depth of the food deficit } \\
\text { (kilocalories per person } \\
\text { per day) }\end{array}$ & $\begin{array}{l}\text { Food and Agriculture Organization, The State of Food } \\
\text { Insecurity in the World } \\
\text { (http://www.fao.org/economic/ess/ess-fs/ess- } \\
\text { fadata/en/\#.VByWLoHGXIg). }\end{array}$ \\
\hline X2 & $\begin{array}{l}\text { Improved water source } \\
\text { (\% of population with access) }\end{array}$ & $\begin{array}{l}\text { WHO/UNICEF Joint Monitoring Programme (JMP) for } \\
\text { Water Supply and Sanitation (http://www.wssinfo.org/). }\end{array}$ \\
\hline X3 & $\begin{array}{l}\text { Life expectancy at birth, total } \\
\text { (years) }\end{array}$ & $\begin{array}{l}\text { (1) United Nations Population Division, (2) United } \\
\text { Nations Statistical Division, (3) National statistical offices, } \\
\text { (4) Eurostat, (5) Secretariat of the Pacific Community, } \\
\text { and (6) U.S. Census Bureau. }\end{array}$ \\
\hline X4 & $\begin{array}{l}\text { GNI per capita } \\
\text { (constant 2005 USD) }\end{array}$ & $\begin{array}{l}\text { World Bank national accounts data, and OECD National } \\
\text { Accounts data files. }\end{array}$ \\
\hline
\end{tabular}

Source: own compilation based on The World Bank's World Development Indicators database.

To measure the level of the socio-economic development in Sub-Saharan Africa a composite index has been created. In order to highlight problems faced by analysed countries, it mainly contains variables pertaining to the basic needs. The choice of variables is dictated by (a) the desire to include few variables in the index, (b) the need for the variables being not too specific, so they can cover a wide spectrum of problems. Thus: the $\mathrm{X} 1$ variable presents the problem of hunger and malnutrition, $\mathrm{X} 2$ deals with access to water problem, X3 covers all matters related to health (as diseases such as 
HIV/AIDS, malaria, tuberculosis, or measles significantly shorten life expectancy), and X4 serves as a proxy for poverty and general level of economic development. All used variables and their sources are presented in Table 1 . Variables used in the index correspond with two out of eight Millennium Development Goals: Eradicate Extreme Poverty and Hunger, and Combat HIV/AIDS, Malaria and Other Diseases (with other MDG being: Achieve Universal Primary Education, Promote Gender Equality and Empower Women, Reduce Child Mortality, Improve Maternal Health, Ensure Environmental Sustainability, and Global Partnership for Development).

It has been contemplated to include also the improved sanitation facilities (\% of population with access) variable, but it was unduly correlated with other variables. The rest of the variables used are not strongly correlated, and their coefficients of variation being above $10 \%$ suggest good ability to differentiate the phenomenon in question. Their descriptive statistics are presented in Table 2.

Table 2. Descriptive statistics of the variables in analysed Sub-Saharan countries in 2012

\begin{tabular}{|l|r|r|r|r|}
\hline & $\begin{array}{c}\text { X1 (Depth of the } \\
\text { food deficit, } \\
\text { kilocalories per } \\
\text { person per day) }\end{array}$ & $\begin{array}{c}\text { X2 (Improved } \\
\text { water source, } \\
\text { \% of } \\
\text { population } \\
\text { with access) }\end{array}$ & $\begin{array}{c}\text { X3 (Life } \\
\text { expectancy } \\
\text { at birth, } \\
\text { years) }\end{array}$ & $\begin{array}{c}\text { X4 (GNI per } \\
\text { capita } \\
\text { (constant } \\
\text { 2005 USD) }\end{array}$ \\
\hline Mean & 160.690 & 73.131 & 57.890 & 1707.489 \\
\hline Standard Deviation & 114.972 & 15.293 & 6.812 & 2674.170 \\
\hline Maximum value & 167.000 & 99.800 & 74.544 & 13889.950 \\
\hline Minimum value & 16.000 & 49.200 & 45.329 & 153.143 \\
\hline $\begin{array}{l}\text { Character } \\
\text { of the variable }\end{array}$ & $\begin{array}{c}\text { Destimulant, } \\
\text { changed into } a \\
\text { stimulant using the } \\
\text { following formula*: } \\
x 1_{i}^{\prime}=2 * \overline{x 1}-x 1_{i}\end{array}$ & Stimulant & Stimulant & Stimulant \\
\hline
\end{tabular}

* formula used to change destimulant into a stimulant taken from: (Zeliaś 2004, p.62)

Source: own compilation and calculation based on data from The World Bank's World Development Indicators database.

Six Sub-Saharan countries have been eliminated from the analysis due to the lack of data. These are: Comoros, Democratic Republic of Congo, Equatorial Guinea, Eritrea, Somalia, and South Sudan. The analysis is static; it is concerned only with the present situation in Sub-Saharan Africa, 2012 being the most recent year with full data available. Of course, analysed countries differ in socio-economic aspects like poverty, education, health or income. Life expectancy in Cape Verde in 2013 was 75.1 years, while in Swaziland it was only 49.0 years. Mean years of schooling in 2012 was 9.9 in South Africa, while in Burkina Faso it was only 1.3 years. Gross national income per capita in 2013 (in 2011 PPP USD) was 24632 in Seychelles, while in Central African Republic it was only 588 USD. In Burundi 81.32\% of population lives below the poverty line (1.25 PPP USD), in Gabon this percentage is $4.84 \%^{1}$. Despite these differences Sub-Saharan Africa is often analysed as one region. This paper attempts to study those differences.

\footnotetext{
${ }^{1}$ All data in this paragraph are taken from UNDP.
} 
Data have been normalized using quotient transformation (with the mean as a base for transformation). The composite index is the arithmetic mean of normalized values of the variables. In order to verify the hypotheses parametric tests are used.

\section{RESULTS AND DISCUSSION}

The results of the analysis show that the socio-economic development level of the majority of the Sub-Saharan countries is close to the average. As much as 36 countries fit in the one standard deviation from the mean interval, with the mean being 1.000 and standard deviation 0.518 .

Twelve Sub-Saharan countries have above-average level of the socio-economic development. These are: Angola (1.031), Benin (1.030), Botswana (1.697), Cabo Verde (1.421), Gabon (2.011), Ghana (1.134), Mauritius (2.051), Namibia (1.369), Nigeria (1.029), Sao Tome and Principe (1.188), Seychelles (3.101), and South Africa (1.904). Some of them are rich in natural resources (oil and others); some derive a substantial part of their income from tourism. Not even one belongs to the group of inland countries without significant natural resources. Seychelles is a special case. Their value of the composite index of the socio-economic development is 3.101. This appears to be an outlier value; it exceeds the mean by more than a tripled standard deviation. This result is mostly influenced by the GNI per capita component of the composite index: in 2012 GNI per capita in Seychelles amounted to 13890 USD.

The level of the socio-economic development of 30 countries is below-average. The lowest level of development can be observed in Burundi (0.083); other low-development countries are: Ethiopia (0.486), Mozambique (0.499), Zambia (0.574), Sudan (0.579), Sierra Leone (0.623), Chad (0.644), Tanzania (0.648), Central African Republic (0.684), and Madagascar (0.689). The probability distribution of the values of the composite index is positively (non-zero) skewed.

Analysing the level of the socio-economic development in the geographical subregions of Sub-Saharan Africa, it can be observed that East Africa (Burundi, Ethiopia, Kenya, Rwanda, Seychelles, Sudan, Tanzania, and Uganda) has the lowest level of development (0.900). West Africa's (Benin, Burkina Faso, Cabo Verde, Cote d'Ivoire, Gambia, Ghana, Guinea, Guinea-Bissau, Liberia, Mali, Mauritania, Niger, Nigeria, Senegal, Sierra Leone, and Togo) value of the composite index reached 0.945. Central Africa (Cameroon, Central African Republic, Chad, Congo, Gabon, and Sao Tome and Principe) scored slightly above average: 1.071. The most developed proved to be South Africa (Angola, Botswana, Lesotho, Madagascar, Malawi, Mauritius, Mozambique, Namibia, South Africa, Swaziland, Zambia, and Zimbabwe), with the composite index reaching 1.104. However, parametric tests show that all sub-regional results do not differ significantly from the average level of the socio-economic development in the whole Sub-Saharan Africa (Table 3). 


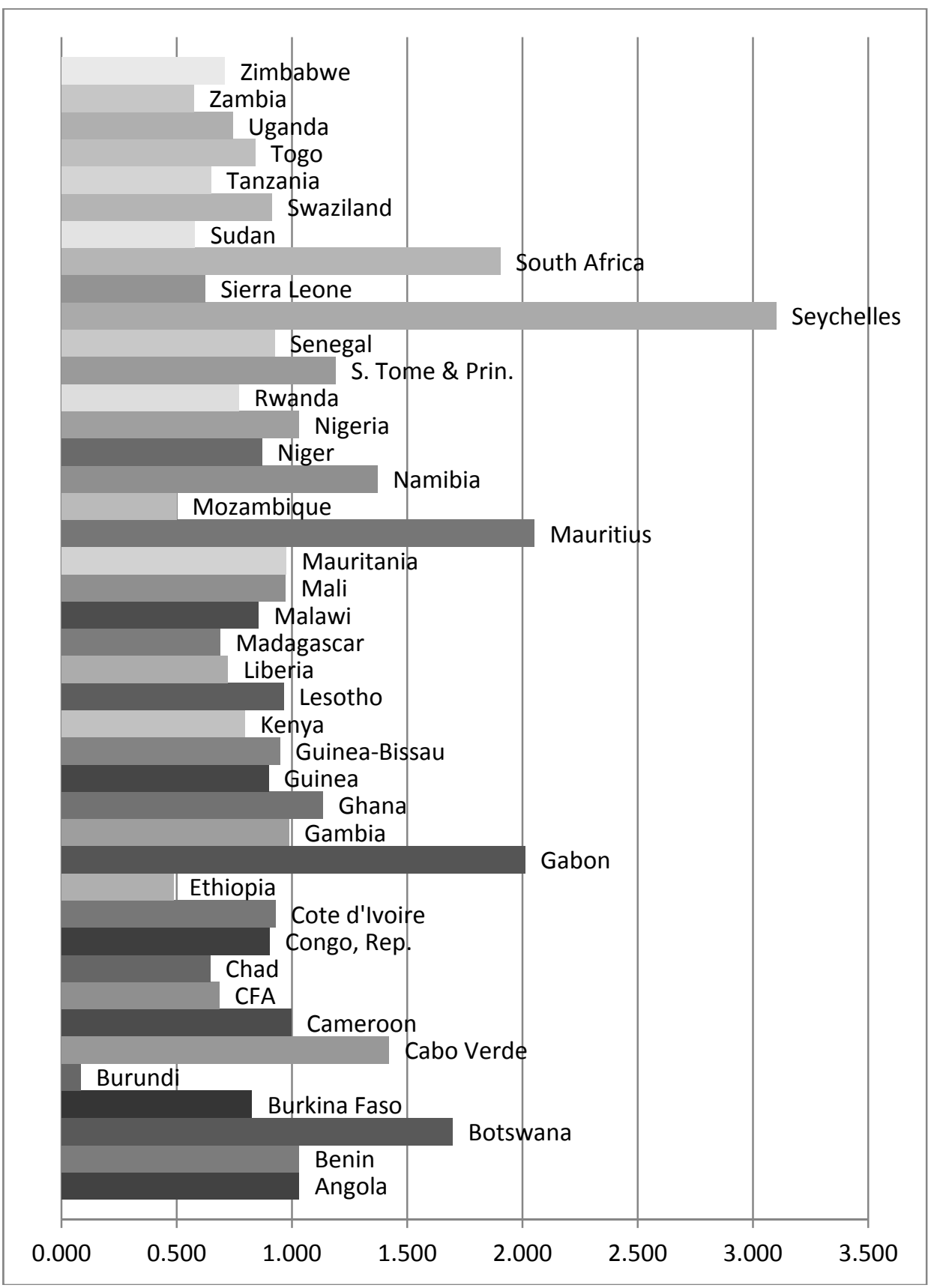

Figure 1. Values of the socio-economic development composite index in 2012 for analysed Sub-Saharan countries

Source: own compilation and calculation based on data from The World Bank's World Development Indicators database. 
Table 3. Results of the parametric tests (version with Seychelles)

\begin{tabular}{|l|c|r|r|r|c|}
\hline \multicolumn{1}{|c|}{ Analysed sub-region } & M & \multicolumn{1}{c|}{ SD } & N & H0: & p-value \\
\hline Central Africa & 1.071 & 0.502 & 6 & $\mathrm{M}=1$ & $0.764(0.382)$ \\
\hline East Africa & 0.900 & 0.918 & 8 & $\mathrm{M}=1$ & $0.782(0.391)$ \\
\hline West Africa & 0.945 & 0.177 & 16 & $\mathrm{M}=1$ & $0.247(0.124)$ \\
\hline South Africa & 1.104 & 0.527 & 12 & $\mathrm{M}=1$ & $0.526(0.263)$ \\
\hline \multicolumn{5}{|l|}{} \\
\hline South Africa/West Africa & $\mathrm{x}$ & $\mathrm{x}$ & $\mathrm{x}$ & $\mathrm{M}_{\mathrm{SA}}=\mathrm{M}_{\mathrm{WA}}$ & $0.268(0.134)$ \\
\hline South Africa/East Africa & $\mathrm{x}$ & $\mathrm{x}$ & $\mathrm{x}$ & $\mathrm{M}_{\mathrm{SA}}=\mathrm{M}_{\mathrm{EA}}$ & $0.534(0.267)$ \\
\hline South Africa/Central Africa & $\mathrm{x}$ & $\mathrm{x}$ & $\mathrm{x}$ & $\mathrm{M}_{\mathrm{SA}}=\mathrm{M}_{\mathrm{CA}}$ & $0.901(0.450)$ \\
\hline
\end{tabular}

M - mean; SD - standard deviation; $\mathrm{N}$ - sample size; $\mathrm{HO}$ - zero hypothesis; $\mathrm{p}$-values for one-tailed tests in the brackets.

Source: own calculations based on data from The World Bank's World Development Indicators database.

South Africa's level of the socio-economic development, even though the highest among the sub-regions of Sub-Saharan Africa, isn't significantly higher than the level of development in West Africa ( $p=0.134$ for one-tailed test), East Africa ( $p=0.267$ for onetailed test), nor Central Africa ( $p=0.450$ for one-tailed test).

If Seychelles is eliminated from the analysis as an outlier value, East Africa's level of the socio-economic development decreases rapidly to 0.534 . It proves to be significantly lower than that of other sub-regions (West Africa: $p=0.000$, Central Africa: $p=0.017$, South Africa: $p=0.008$; $p$-values for one-tailed tests). It is also significantly lower than the average level of the socio-economic development in the whole Sub-Saharan Africa $(p=0.006)$. Other results do not change much after removing Seychelles. Other subregions' level of development is still not significantly different from the average level in Sub-Saharan Africa, and South Africa's level is not significantly higher in comparison to West and Central Africa (See Table 4; South Africa's level is higher than West Africa's for the level of significance $\alpha=0.1$ ).

Table 4. Results of the parametric tests (after eliminating Seychelles)

\begin{tabular}{|l|c|r|r|r|c|}
\hline \multicolumn{1}{|c|}{ Analysed sub-region } & M & SD & N & HO: & p-value \\
\hline Central Africa & 1.139 & 0.570 & 6 & $\mathrm{M}=1$ & $0.609(0.304)$ \\
\hline East Africa & 0.534 & 0.315 & 7 & $\mathrm{M}=1$ & $0.011(0.006)$ \\
\hline West Africa & 0.973 & 0.191 & 16 & $\mathrm{M}=1$ & $0.588(0.296)$ \\
\hline South Africa & 1.194 & 0.602 & 12 & $\mathrm{M}=1$ & $0.308(0.154)$ \\
\hline \multicolumn{7}{|l|}{} \\
\hline South Africa/West Africa & $\mathrm{x}$ & $\mathrm{x}$ & $\mathrm{x}$ & $\mathrm{M}_{\mathrm{SA}}=\mathrm{M}_{\mathrm{WA}}$ & $0.177(0.089)$ \\
\hline South Africa/East Africa & $\mathrm{x}$ & $\mathrm{x}$ & $\mathrm{x}$ & $\mathrm{M}_{\mathrm{SA}}=\mathrm{M}_{\mathrm{EA}}$ & $0.016(0.008)$ \\
\hline South Africa/Central Africa & $\mathrm{x}$ & $\mathrm{x}$ & $\mathrm{x}$ & $\mathrm{M}_{\mathrm{SA}}=\mathrm{M}_{\mathrm{CA}}$ & $0.855(0.427)$ \\
\hline East Africa/West Africa & $\mathrm{x}$ & $\mathrm{x}$ & $\mathrm{x}$ & $\mathrm{M}_{\mathrm{EA}}=\mathrm{M}_{\mathrm{WA}}$ & $0.000(0.000)$ \\
\hline East Africa/Central Africa & $\mathrm{x}$ & $\mathrm{x}$ & $\mathrm{x}$ & $\mathrm{M}_{\mathrm{EA}}=\mathrm{M}_{\mathrm{CA}}$ & $0.034(0.017)$ \\
\hline
\end{tabular}

M - mean; SD - standard deviation; N - sample size; HO - zero hypothesis; $p$-values for one-tailed tests in the brackets.

Source: own calculations based on data from The World Bank's World Development Indicators database. 


\section{CONCLUSIONS}

Despite dynamic GDP growth in Sub-Saharan Africa, this region faces serious problems with providing for its inhabitants' basic needs. This suggests that a stronger focus should be put on the socio-economic development of the region, and on indices measuring those basic needs. This article was an attempt to answer this issue.

The results of the research show that the level of the socio-economic development in Sub-Saharan Africa is not very diverse spatially. Most of the countries share a similar level of development, close to the average level for the whole region. What is more, there are also no significant differences in the level of the socio-economic development between the geographical sub-regions: Central, West, East, and South Africa. This means the first hypothesis should be discarded. Situation is similar with the other two hypotheses. South Africa indeed has the highest level of the socio-economic development, but it is not statistically significant. No region differs significantly from the others, be it positively or negatively. The second hypothesis also must be discarded. The third hypothesis posited that after eliminating countries with extreme values (which proved to be only Seychelles), the overall results would be closer to the average and not statistically significant. The opposite proved to be true. Removing Seychelles from the analysis pushed East Africa's level of the socio-economic development down. It proved to be significantly lower than that of the other sub-regions and the whole Sub-Saharan Africa.

A question is sometimes raised whether it is justified to group all the Sub-Saharan countries and analyse them as one region. These results show that despite obvious differences in macroeconomic situation or sociological and historical determinants between Sub-Saharan countries, their level of the socio-economic development is not significantly different. Of course it all depends on the variables taken into consideration, but it seems appropriate to focus on basic needs, as opposed to higher needs when analysing developed countries. The similar level of development across Sub-Saharan Africa justifies treating Sub-Saharan countries as one region.

As it has been already mentioned, the results are strongly dependent on used measures of the socio-economic development. The issue is definitely worth exploring further with a different set of variables comprising the composite index. The author also plans a more in-depth study focusing on the relation (or in some cases the lack thereof) between the economic growth and the standard of living in Sub-Saharan Africa.

\section{REFERENCES}

Acemoglu, D., \& Robinson, J.A. (2010). Why is Africa poor? Economic History of Developing Regions, 25(1), 21-50.

Adams, S. (2009). Can foreign direct investment (FDI) help to promote growth in Africa? African Journal of Business Management, 3(5), 178-183.

Bhattacharyya, S. (2009). Root Causes of African Underdevelopment. Centre for the Study of African Economies (CSAE). Journal of African Economies, 18(5), 745-780.

Boccanfuso, D., Savard, L., \& Savy, B.E. (2013). Human capital and growth: new evidences from African data. International Economic Journal, 27(1), 55-77. 
Boone, P. (1996). Politics and the effectiveness of foreign aid. European Economic Review, 40, 289-329.

Burnside, C., \& Dollar, D. (1997). Aid, Policies, and Growth. Policy Research, No. 1777, Washington, DC: World Bank.

Collier, P., \& Gunning, J. W. (1999). Explaining African economic performance. Journal of Economic Literature, 37(1), 64-111.

Collier, P., \& Hoeffler, A.E. (1998). On economic causes of civil war. Oxford Economic Papers, 50, 563-73.

Dulani, B., Mattes, R., \& Logan, C. (2013). After a Decade of Growth in Africa, Little Change in Poverty at the Grassroots. Policy Brief No. 1, Afrobarometer.

Easterly, W., \& Levine, R. (1997). Africa's growth tragedy: policies and ethnic divisions. The Quarterly Journal of Economics, 112(4), 1203-1250.

Elbadawi, I., Ndulu, B. J., \& Ndung'u, N. (1997). Debt overhang and economic growth in SubSaharan Africa. In Z. Iqbal, R. Kanbur (Eds.), External finance for low-income countries (pp. 4976). International Monetary Fund.

Fosu, A.K. (1992a). Political instability and economic growth: evidence from Sub-Saharan Africa. Economic Development and Cultural Change, 40(4), 829-41.

Fosu, A.K. (1992b). Effect of export instability on economic growth in Africa. Journal of Developing Areas, 26(3), 323-332.

Ghura, D., \& Hadjimichael, M.T. (1996). Growth in Sub-Saharan Africa. Staff Papers-International Monetary Fund, 43(3), 605-634.

$\mathrm{Gu}$, J. (2009). China's private enterprises in Africa and the implications for African development. European Journal of Development Research, 21(4), 570-587.

Gupta, S., Pattillo, C.A., \& Wagh, S. (2009). Effect of remittances on poverty and financial development in Sub-Saharan Africa. World Development, 37(1), 104-115.

Gyimah-Brempong, K., \& Traynor, T.L. (1999). Political Instability, Investment and Economic Growth in Sub-Saharan Africa. Journal of African Economies, 8, 52-86.

Kaplinsky, R., McCornick, D., \& Morris, M. (2007). The Impact of China on Sub-Saharan Africa. IDS Working Paper, 291.

Karshenas, M. (2001). Agriculture and economic development in Sub-Saharan Africa and Asia. Cambridge Journal of Economics, 25(3), 315-342.

Kraay, A., \& Raddatz, C. (2007). Poverty traps, aid, and growth. Journal of Development Economics, 82(2), 315-347.

Lumbila, K.N. (2005). What makes FDI Work? A Panel Analysis of the Growth Effect of FDI in Africa. Africa Region Working Paper Series, No.80, February, Washington, DC: World Bank.

Nunn, N. (2008). The long-term effects of Africa's slave trades. Quarterly Journal of Economics, 123(1), 139-176.

Platteau, J.-P. (2000). Institutions, Social Norms, and Economic Development. Amsterdam: Psychology Press.

Platteau, J.-P. (2009). Institutional obstacles to African development: State, ethnicity, and custom. Journal of Economic Behavior \& Organization, 71(3), 669-689.

Sachs, J.D., \& Warner, A.M. (1997). Sources of slow growth in African economies. Journal of African Economies, 6(3), 335-376.

Zeliaś, A. (Ed.) (2004). Poziom życia w Polsce i krajach Unii Europejskiej. Warszawa: Polskie Wydawnictwo Ekonomiczne. 


\section{Author}

\section{Agnieszka Witoń}

Master's degree in economics (specialization in international economics) from Jagiellonian University in Kraków (2013). Currently enrolled in the PhD studies at Cracow University of Economics (Poland). Doctoral dissertation covers the issue of the relation between the standard of living and economic growth in Sub-Saharan Africa.

\section{Correspondence to:}

Agnieszka Witoń, M.Sc.

Cracow University of Economics

ul. Rakowicka 27, 31-510 Kraków, Poland

a.witon@gmail.com

\section{Copyright and License}

This article is published under the terms of the Creative Commons Attribution - NonCommercial - NoDerivs (CC BY-NC-ND 3.0) License http://creativecommons.org/licenses/by-nc-nd/3.0/ 
